\title{
ТОВАРОЗНАВЧА ПОЛІТИКА ГОТЕЛЬНО-РЕСТОРАННИХ ПОСЛУГ В МІЖНАРОДНОМУ ТУРИСТИЧНОМУ БІЗНЕСІ
}

\section{COMMODITY POLICY OF HOTEL AND RESTAURANT SERVICES IN INTERNATIONAL TOURIST BUSINESS}

\author{
Чуєва Інна Олександрівна \\ кандидат наук фрізичного виховання і спорту, доцент, \\ Запорізький національний університет \\ ORCID: https://orcid.org/0000-0001-8697-7602 \\ Криволапов Едуард Анатолійович \\ старший викладач, \\ Запорізький національний університет \\ ORCID: https://orcid.org/0000-0002-1211-7869 \\ Chuieva Inna, Kryvolapov Eduard \\ Zaporizhzhya National University
}

\begin{abstract}
У статті розглянуто актуальні проблеми товарознавчої політики сфрери гостинності, виявлено ризики, які можуть початися, якщо ці проблеми не будуть своєчасно вирішені. 3 деяких проблем представлені шляхи вирішення. Крім того, частково представлено стратегічні завдання розвитку та вдосконалення товарознавчої політики готельно-ресторанних послуг; охарактеризовано пріоритетні напрямки використання товарів в готельно-ресторанних послугах, до числа яких відноситься: управління асортиментом товарів та послуг, їх фрормування та оцінка, поліпшені споживчі властивості інноваційних товарів, ідентифікація товарів та виявлення їх фральсифрікацій, забезпечення збереження вмісту товарів. Товарознавча політика як складова міжнародного туристичного бізнесу, яка розкриває основні характеристики товарів та готельно-ресторанних послуг, націлена на виконання таких видів діяльності, як наукова, освітня та практична професійна товарознавча.

Ключові слова: товарознавча політика, товар, товарознавство, готельно-ресторанні послуги, міжнародний туристичний бізнес, напрямки розвитку, характеристика товару.
\end{abstract}

В статье рассмотрены актуальные проблемы товароведческой политики сферы гостеприимства, обнаружено риски, которые могут начаться, если эти проблемы не будут своевременно решены. С некоторых проблем представлены пути решения. Кроме того, частично представлены стратегические задачи развития и совершенствования товароведческой политики гостинично-ресторанных услуг; охарактеризованы приоритетные направления использования товаров в гостинично-ресторанных услугах, к числу которых относится: управление ассортиментом товаров и услуг, их формирование и оценка, улучшенные потребительские свойства инновационных товаров, идентификация товаров и выявление их фральсификаций, обеспечение сохранности содержимого товаров. Товароведческая политика как составная международного туристического бизнеса, которая раскрывает основные характеристики товаров и гостинично-ресторанных услуг, нацелена на выполнение таких видов деятельности, как научная, образовательная и практическая профессиональная товароведческая.

Ключевые слова: товароведческая политика, товар, товароведение, гостинично-ресторанные услуги, международный туристический бизнес, направления развития, характеристика товара.

The article considers the current problems of commodity policy in the field of hospitality, identifies the risks that may begin if these problems are not addressed in a timely manner. Some problems are solved. In addition, the strategic objectives of development and improvement of commodity policy of hotel and restaurant services are partially presented; the priority directions of use of goods in hotel and restaurant services are characterized, which include: management of assortment of goods and services, their formation and estimation, improved consumer properties of innovative goods, identification of goods and detection of their falsifications, preservation of goods content. Commodity policy as a component of international tourism business, which reveals the main characteristics of goods and hotel and restaurant services, aimed at performing such activities as scientific, educational and practical professional commodity research. In recent years, research has been virtually discontinued on the development of innovative storage technologies, although this is very important to ensure food independence of the country. At new product 
development, mainly the efforts of researchers are limited to establishing expiration dates in compliance with previously regulated storage conditions. New storage technologies are not used. Possible risks are: obsolescence of traditional storage technologies and, accordingly, the country's backwardness in this direction; growth of commodity losses and irrational use of food resources; rising food prices. To prevent or mitigate these risks it is necessary to conduct research on the development of innovative technologies taking into account modern logistics schemes and chains, at it is expedient to combine the efforts of commodity experts with the efforts of logisticians. Thus, the analysis of these problems scientific commodity science shows the inevitability of risks if these problems are not solved. To prevent risks or mitigate their consequences solve a number of strategic tasks and identify priority directions of scientific development research in the field of commodity science.

Keywords: commodity policy, commodity, commodity science, hotel and restaurant services, international tourist business, directions of development, product characteristics.

Постановка проблеми. Найважливішу проблему наукової товарознавчої політики можна визначити як недостатність фондаментальних досліджень в цій області, про що свідчить відсутність монограсрій і дисертацій з питань методології товарознавчої політики сорери гостинності.

Більшість публікацій з визначеної тематики, які носять прикладний характер, спрямовані на вирішення таких конкретних задач:

- вдосконалення асортименту готельноресторанних послуг шляхом розробки інноваційних товарів;

- фрормування і оцінка споживчих властивостей нових товарів та послуг;

- забезпечення зберігання товарів і встановлення термінів їх придатності;

- виявлення критеріїв і показників ідентифрікації товарів для виявлення їх фральсифрікації, а також для встановлення належності до певних товарних груп;

- забезпечення безпеки товарів;

- розробка інноваційних технологій зберігання харчових продуктів;

- визначення товарних втрат і заходів по їх скороченню або попередження;

- оцінка конкурентоспроможності товарів та послуг.

Аналіз останніх досліджень і публікацій. До числа наукових публікацій останніх десяти років в області теоретико-методологічних основ товарознавства можна віднести роботи, в яких були розглянуті концепція, актуальні проблеми розвитку і вдосконалення товарознавчої політики, представлені теоретичні підходи до розробки інноваційного товарознавства [4-6].

Друга актуальна проблема наукової товарознавчої політики - недостатність фрінансування теоретичних і прикладних товарознавчих досліджень. Певною мірою це обумовлено тим, що результати досліджень призначені, в основному, для підприємств приватного бізнесу, керівники яких не зацікавлені в їх проведенні і не хочуть обтяжувати себе інвестиціями в науку.
Органи державної виконавчої влади, що розподіляють бюджетні кошти на конкурсній основі, віддають перевагу науковим роботам в економічній, соціальній або інфрормаційній сорері.

Одним із шляхів вирішення названих вище проблем може служити інтегрований підхід на характеристику товарознавства, економіки, маркетингу, фрізіології харчування, який здійснюється силами вчених наукових і освітніх установ. Приклади поєднання товарознавчих досліджень 3 гігієнічними випробуваннями представлені в ряді захищених докторських дисертацій (М.О. Ніколаєвої, Ю.І. Сидоренка) [6-7]. На стику товарознавчої політики та економіки була виконана і захищена докторська дисертація Н.С. Алексеєва [1].

Виділення невирішених раніше частин загальної проблеми. Разом 3 тим шляхи вирішення актуальних проблеми товарознавчої політики в міжнародному туристичному бізнесі має певні ризики - «розмивання» проблем товарознавства, сліпе дублювання окремих теоретичних положень інших наук, ставлять товарознавчу політику сфрери гостинності в тупикову ситуацію.

Більш перспективним науковим напрямком $€$, на нашу думку, розгляд потреб, що задовольняються певними послугами готельноресторанної ссрери, причому з урахуванням того, що кожна послуга має здатність задовольнити комплекс індивідуальних потреб споживача. Виходячи з таких потреб слід розробляти нові товари й послуги і здійснювати їх просування на ринку [3].

Так, харчові продукти, що входять до складу готельно-ресторанних послуг, задовольняють фрізіологічні, психічні потреби, а окремі види і торгові марки (наприклад, осетрова і лососева ікра, елітний алкоголь) престижні потреби.

Формулювання цілей статті (постановка завдання). Цілі статті - виявлення актуальних проблем наукової товарознавчої політики готельно-ресторанних послуг, визначення напрямків подальшого розвитку та вдоскона- 
лення наукової товарознавчої політики в міжнародному туристичному бізнесі.

Виклад основного матеріалу дослідження. Однак для цілей товарознавчої політики не прийнятні такі класифікації потреб, як піраміда потреб А. Маслоу і різновид цієї концепції - теорія придбаних потреб Д. МакКлелланда, згідно з якою людям притаманні лише три потреби - влади, успіху і причетності [3, с. 21]. Ніколаєвою М.А. запропонована розгорнута класифікація потреб з розподілом на п'ять видів: фрізіологічні, психічні, духовні, соціально-економічні та інтелектуальні [6].

Кожен вид підрозділяється на різновиди. При визначенні різновидів фрізіологічних і психічних потреб враховані споживчі властивості харчових продуктів, що входять до складу готельно-ресторанної послуги. Так, до різновидів фрізіологічних потреб, що задовольняються харчовими продуктами, відносяться енергетичні, пластичні, а також потреби у воді, в підтримці температурного гомеостазу, потреба в безпеці внутрішнього середовища людини. Зазначені потреби задовольняються за рахунок надходження в організм людини енергетичних, біологічних активних речовин, води, харчових продуктів за умови їх безпеки.

Питання про потреби, що задовольняються товарами та послугами, є ключовим не тільки для товарознавчої політики, але і для маркетингу, а також для управління якістю в сорері гостинності, оскільки потреби - це найважливіші об'єкти маркетингу, а товар чи послуга як засіб задоволення потреб відноситься до об'єктів товарознавства. Основний принцип систем менеджменту якості - орієнтація на споживачів - передбачає виявлення і задоволення потреб (запитів) споживачів, що особливо важливо при проектуванні нових товарів та послуг і просування їх на ринок. Як зазначалося раніше, цей напрямок товарознавства в даний час знаходить реальне втілення в наукових товарознавчих. Ще однією 3 важливих проблем сучасної товарознавчої політики в сорері туристичного бізнесу є нерозуміння важливості та актуальності застосування математичного апарату, а також інфрормаційних технологій в наукових товарознавчих роботах, в першу чергу в докторських і кандидатських дисертаціях. Автори окремих дисертацій застосовують математичні методи 3 метою прогнозування оптимального числа об'єктів дослідження, а також підвищення якості та оптимізації термінів придатності товарів, що є складовими послуг готельноресторанної сорери [4].
Крім того, для товарознавчої політики як складової міжнародного туристичного бізнесу, як і для будь-якої діяльності, повинні бути визначені пріоритетні напрямки розвитку, які розробляються на основі аналізу історичних і сучасних шляхів розвитку.

Наступною проблемою товарознавчої політики сорери гостинності є слабка доказовість ідентифрікаційної та кваліметричної бази і недостатня достовірність переліку ідентифікованих показників, в тому числі ті, що наведені у технічних регламентах. Адже більшість регламентованих показників і їх значень для цілей ідентифрікації піддаються фральсифікації (наприклад, масова частка жиру і білка - регламентоване значення, яке легко фральсифікується за рахунок рослинних масел і соєвого білка). У ряді випадків відсутні або не належать до стандартизованих методи випробувань ідентифрікованих показників (наприклад, метод визначення сухого молока, яке додається в питне молоко), так і прилади для вимірювань відсутні в багатьох випробувальних лабораторіях (наприклад, для визначення ГМО-джерел). У випадку, якщо зазначена проблема не буде вирішена, можливі наступні ризики: дискредитація процедури ідентиорікації, недостовірність ії результатів; збільшення кількості фральсифрікованих, в тому числі контрафрактних, товарів, що реалізуються в готельно-ресторанному бізнесі. Щоб попередити ці ризики, для товарів кожної однорідної групи, що є складовими готельно-ресторанних послуг і кожного виду потрібно визначити мінімально необхідний перелік ідентифрікуючих показників, які важко або економічно недоцільно фральсифікувати. Поки таких показників дуже мало, а наявні наукові розробки не впроваджуються в практику [5].

Поряд з визначенням ідентисрікації показників за допомогою складних і дорогих вимірювальних методів слід здійснювати пошук або розробку недорогих експрес-методів при великих готельно-ресторанних комплексах 3 використанням реакцій виявлення специфічних для даного продукту речовин або, навпаки, не властивих йому.

Прикладом такого експрес-методу є визначення крохмалю за допомогою йодокрохмальної проби в молочних продуктах - кисломолочних напоях, сметані, сирі, згущеному молоці тощо.

Разом з тим у багатьох молочних, кондитерських виробах (в шоколаді, кремах тощо) інколи проводиться заміна молочного жиру або какао-масла на тверді рослинні жири, спреди або маргарин. Тому розробка та впровадження експрес-методів визначення зазна- 
чених фральсифрікатів відноситься до числа першочергових завдань товарознавчої політики готельно-ресторанних послуг.

Ще однією актуальною проблемою ослаблення уваги до питань забезпечення зберігання товарів, в тому числі інноваційних. В останні роки практично припинено проведення досліджень, спрямованих на розробку інноваційних технологій зберігання, хоча це і дуже важливо для забезпечення продовольчої незалежності готельно-ресторанних послуг як складової міжнародного туристичного бізнесу. При розробці нових страв в ресторанах, в основному, зусилля менеджерів відділу їжі та напоїв зводяться до встановлення термінів придатності при дотриманні раніше регламентованих умов зберігання. Нові технології зберігання при цьому не застосовуються [6].

Можливі ризики такі: старіння традиційних технологій зберігання і, відповідно, відставання країни в даному напрямку; зростання товарних втрат і нераціональне використання продовольчих ресурсів; підвищення цін на продукти харчування . Для запобігання або мінімізації зазначених ризиків необхідно проводити дослідження з розробки інноваційних технологій з урахуванням сучасних логістичних схем і ланцюгів, при цьому доцільно зусилля товарознавців об'єднати з зусиллями логістів [7].

Висновки. Таким чином, аналіз зазначених проблем товарознавчої політики показує неминучість виникнення ризиків, якщо ці проблеми не будуть вирішені. Для запобігання ризикам або пом'якшення їх наслідків має бути вирішити ряд стратегічних завдань і визначити пріоритетні напрямки розвитку наукових досліджень в галузі товарознавства [8].

Вважаємо за можливе віднести до числа пріоритетних наступні напрямки:

- управління асортиментом продовольчих товарів, включених до готельно-ресторанних послуг, включаючи категорійний менеджмент товарів;

- фрормування і оцінка поліпшених споживчих властивостей інноваційних споживчих товарів, в тому числі продуктів фрункціонального і спеціалізованого призначення;

- ідентифікація та виявлення фральсифікації продовольчих товарів;

- забезпечення безпеки споживчих товарів;

- забезпечення зберігання продовольчих товарів шляхом розробки інноваційних технологій зберігання;

- оцінка конкурентоспроможності товарів і есрективності товарознавчих методів ії̈ забезпечення в міжнародному туристичному бізнесі;

- визначення товарних втрат і встановлення причин їх виникнення;

- вплив зовнішніх і внутрішніх фракторів на збереженість продовольчих або непродовольчих товарів при готельно-ресторанних комплексах;

- порівняльна характеристика споживчих властивостей вітчизняних та імпортних одновидових товарів різних торгових марок.

Проведення наукових товарознавчих досліджень повинно здійснюватися на інтегрованої основі 3 використанням підходів і методів 3 інших суміжних галузей знань - маркетингу, логістики, економіки, соціології, математики, стандартизації, метрології тощо.

\section{СПИСОК ВИКОРИСТАНИХ ДЖЕРЕЛ:}

1. Алексеев Н.С., Кутянин Г.И., Ганцов Ш.К. Теоретические основы товароведения. Москва : Экономика, 2008. $234 \mathrm{c}$.

2. Парамонова Т.Н. Маркетинг. Москва : КНОРУС, 2012. 312 с.

3. Макклеланд Д. Мотивація людини. СПБ. : Пітер, 2007. 432 с.

4. Ніколаєва М.О. Актуальні проблеми розвитку і вдосконалення товарознавства. Товарознавство і торгове підприємництво: дослідження, інновації і освіта : зб. наук. та. міжнар. наук.-практ. конфр. Київ : КТЕУ, 2011. № 5. C. 19-22.

5. Ніколаєва М.О. Концепція розвитку і вдосконалення товарознавства. Технології товарознавства інноваційних харчових продуктів. 2011. № 2. С. 63-69.

6. Николаева М.А. Товарная политика. Москва : Норма; ИНФРА-М, 2015. 180 с.

7. Сидоренко Ю.И., Голяк Ю.П., Султанович Ю.А. Применение методики ускоренного старения для оценки окислительной стабильности масел и жиров. Товароведение, общественное питание и технология хранения продовольственных товаров : сб. материалов VI Межведомств. науч.-практ. конор. Москва : Библиотечно-издательский комплекс МГУПП, 2014. С. 68-73.

8. Сидоренко Ю.И., Семенова Е.А., Мастихина А.Л. Концепция восприятия качества в современном товароведении продовольственных товаров. Товароведение, общественное питание и технология хранения продовольственных товаров : сб. материалов V Межведомств. науч.-практ. конфр. Москва : Библиотечноиздательский комплекс МГУПП, 2013. С. 158-160. 


\section{REFERENCES:}

1. Alekseev N.S., Kutianyn H.Y., Hantsov Sh.K. (2008) Teoretycheskye osnovy tovarovedenyia. Moscow: Ekonomika. (in Russian)

2. Paramonova T.N. (2012). Marketynh. Moscow: KNORUS. (in Russian)

3. Makkleland D. (2007) Motyvatsiia liudyny. SPB.: Piter. (in Russian)

4. Nikolaieva M.O. (2011) Aktualni problemy rozvytku i vdoskonalennia tovaroznavstva. Tovaroznavstvo i torhove pidpryiemnytstvo: doslidzhennia, innovatsii i osvita: zb. nauk. ta. mizhnar. nauk.-prakt. konf. Kyiv: KTEU, no. 5, pp. 19-22. (in Ukrainian)

5. Nikolaieva M.O. (2011) Kontseptsiia rozvytku i vdoskonalennia tovaroznavstva. Tekhnolohii tovaroznavstva innovatsiinykh kharchovykh produktiv, no. 2, pp. 63-69. (in Ukrainian)

6. Nykolaeva M.A. (2015) Tovarnaia polytyka. Moscow: Norma; YNFRA-M. (in Russian)

7. Sydorenko Yu.Y., Holiak Yu.P., Sultanovych Yu.A. (2014) Prymenenye metodyky uskorennoho starenyia dlia otsenky okyslytelnoi stabylnosty masel y zhyrov. Tovarovedenye, obshchestvennoe pytanye y tekhnolohyia khranenyia prodovolstvennykh tovarov: sb. materyalov VI Mezhvedomstv. nauch.-prakt. konf. Moscow: Byblyotechnoyzdatelskyi kompleks MHUPP, pp. 68-73. (in Russian)

8. Sydorenko Yu.Y., Semenova E.A., Mastykhyna A.L. (2013) Kontseptsyia vospryiatyia kachestva v sovremennom tovarovedenyy prodovolstvennykh tovarov. Tovarovedenye, obshchestvennoe pytanye y tekhnolohyia khranenyia prodovolstvennykh tovarov: sb. materyalov V Mezhvedomstv. nauch.-prakt. konf. Moscow: Byblyotechnoyzdatelskyi kompleks MHUPP, pp. 158-160. (in Russian) 